\title{
Nitrate and Nitrite Promote Formation of Tobacco-Specific Nitrosamines via Nitrogen Oxides Intermediates during Postcured Storage under Warm Temperature
}

\author{
Jun Wang, ${ }^{1}$ Huijuan Yang, ${ }^{1}$ Hongzhi Shi, ${ }^{1}$ Jun Zhou, ${ }^{2}$ Ruoshi Bai, \\ Mengyue Zhang, ${ }^{1}$ and Tong Jin ${ }^{1}$ \\ ${ }^{1}$ Henan Agricultural University, National Tobacco Cultivation \& Physiology \& Biochemistry Research Center, \\ Zhengzhou 450002, China \\ ${ }^{2}$ Beijing Cigarette Factory, Shanghai Tobacco Group Co. Ltd., Beijing 100024, China \\ Correspondence should be addressed to Hongzhi Shi; shihongzhi88@163.com
}

Received 26 December 2016; Revised 7 February 2017; Accepted 7 March 2017; Published 29 March 2017

Academic Editor: Yang Xu

Copyright (c 2017 Jun Wang et al. This is an open access article distributed under the Creative Commons Attribution License, which permits unrestricted use, distribution, and reproduction in any medium, provided the original work is properly cited.

\begin{abstract}
Tobacco-specific nitrosamines (TSNAs) are carcinogenic and are present in cured tobacco leaves. This study was designed to elucidate the mechanisms of TSNAs formation under warm temperature storage conditions. Results showed that nitrogen oxides $(\mathrm{NOx})$ were produced from nitrate and nitrite in a short period of time under $45^{\circ} \mathrm{C}$ and then reacted with alkaloids to form TSNAs. Nitrite was more effective than nitrate in promoting TSNAs formation during $45^{\circ} \mathrm{C}$ storage which may be due to the fact that nitrite can produce a large amount of NOx in comparison with nitrate. Presence of activated carbon effectively inhibited the TSNAs formation because of the adsorption of NOx on the activated carbon. The results indicated that TSNAs are derived from a gas/solid phase nitrosation reaction between NOx and alkaloids. Nitrate and nitrite are major contributors to the formation of TSNAs during warm temperature storage of tobacco.
\end{abstract}

\section{Introduction}

Tobacco-specific nitrosamines (TSNAs) are a group of important and toxic components of tobacco and tobacco smoke $[1,2]$. TSNAs mainly consist of $\mathrm{N}$-nitrosonornicotine (NNN), $\mathrm{N}$-nitrosoanatabine (NAT), $\mathrm{N}$-nitrosoanabasine (NAB), and 4-(methyl nitrosamino)-1-(3-pyridyl)-1-butanone (NNK). NNN and NNK are strong carcinogens [3,4]. TSNAs are produced via nitrosation of tobacco alkaloids during the curing and storage of tobacco leaves (Figure 1) [5-8]. In China, both air-cured and flue-cured tobacco leaves are generally stored for approximately 18 months in warehouses before being processed for cigarette production in order to reduce the unfavorable smells [9].

Many studies reported about the factors that influence TSNAs formation during air-curing [7, 10-12]. Cui [10] found that TSNAs levels in the leaf lamina and midrib increased substantially during the fourth to seventh weeks of air-curing stage. During this stage nitrate is reduced to nitrite via microbial activity, and the resulting nitrite, in turn, is involved in nitrosation reactions with the naturally existing alkaloids during air-curing, then leading to the formation of TSNAs (Figure 2) [11].

However, to our knowledge there are few reports available on the mechanisms of TSNAs formation during storage stage. TSNAs levels may increase several fold in comparison to the levels in freshly air-cured leaves $[13,14]$, but the mechanisms of TSNAs formation during storage are not clear. It has been reported that, as the storage temperature increased, TSNAs and nitrite contents increased, and the most rapid increase in TSNAs occurred during the warm temperature season $[15$, 16]. The interactions between temperature and abundant nitrate in cured tobacco leaf could be responsible for TSNAs formation during storage. Treatment of the tobaccos with streptomycin and rifampicin did not inhibit nitrosamine formation during storage indicating that TSNAs formation was 


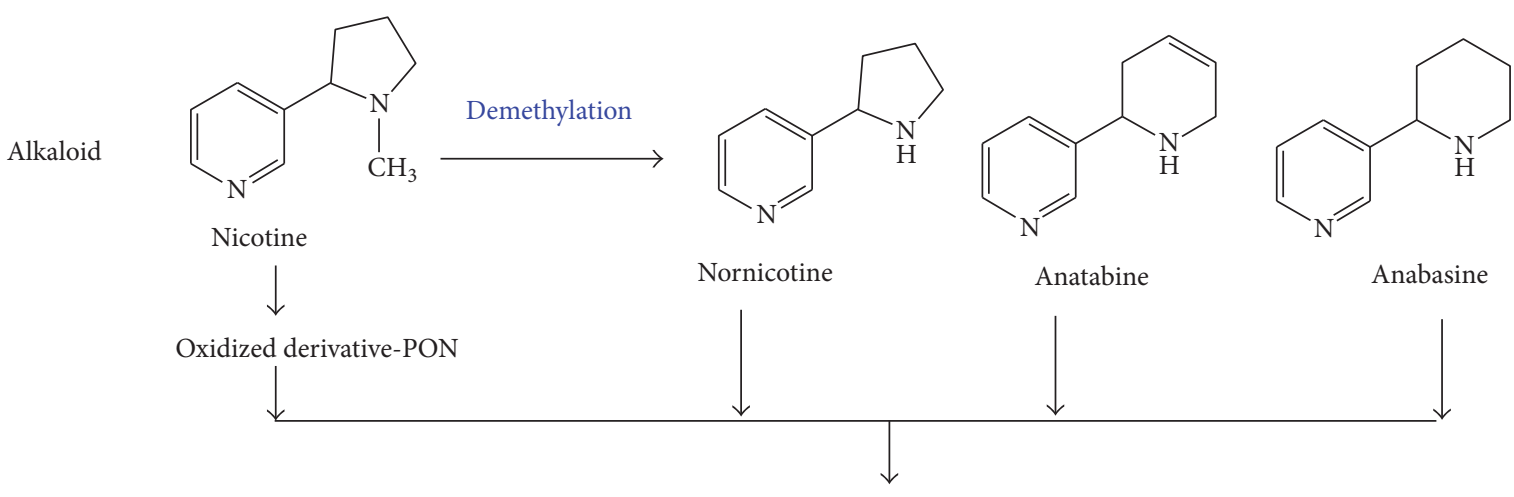<smiles>COC(=O)c1cccnc1</smiles>
Activated nitrosating agents, $\mathrm{NO}_{2}{ }^{-}, \mathrm{NO}, \mathrm{NO}_{2}, \mathrm{~N}_{2} \mathrm{O}_{3}$<smiles>CCCC(c1cccnc1)N1CCCC1N</smiles><smiles>O=NN1CC=CCC1c1cccnc1</smiles><smiles>CCCCC(c1cccnc1)N1CCCCC1[15NH2]</smiles>

FIGURE 1: Proposed formation pathways of the major TSNAs found in cured tobacco leaves. Nitrosating agents can directly interact with nornicotine, anatabine, and anabasine to form NNN, NAT, and NAB, respectively. Nicotine is less susceptible to nitrosation; thus NNK is produced from pseudo-oxynicotine, an oxidized derivative of nicotine.

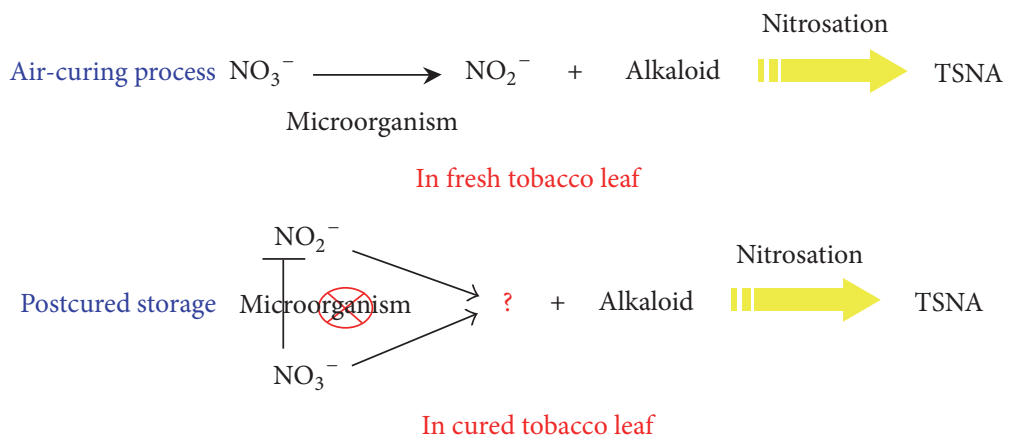

FIGURE 2: The activated nitrosating agents participate in nitrosation of alkaloid to form TSNAs during different processes of air-cured tobacco production. Nitrate $\left(\mathrm{NO}_{3}^{-}\right)$is available for reduction to nitrite $\left(\mathrm{NO}_{2}^{-}\right)$via microbial activity, and the nitrite, in turn, becomes involved in nitrosation reactions with the alkaloids during air-curing, leading to the formation of TSNAs. The nitrite is the most important nitrosating agent during air-curing. TSNAs formation was almost not influenced by microorganism during the storage processes.

not influenced by microorganisms during the storage process (Figure 2) [14]. How the nitrate and nitrite trigger the increase in TSNAs during warm temperature storage is still not clear (Figure 2). The objectives of this study were to elucidate the mechanisms of TSNAs formation during the storage time of cured tobacco leaf and to verify the hypothesis that nitrogen oxides produced from nitrate and nitrite in tobacco are responsible for the formation of TSNAs during storage.

\section{Experiments}

2.1. Plant Materials. Tobacco samples were grown in 2015 and cured locally. Leaves from the middle stalk positions were collected. Flue-cured tobacco (N. tabacum cv. "Hongda") was from Midu county, Yunnan province. Leaf samples were prepared by removing the stems, cut to strips, mixed thoroughly, sealed in plastic bags, and then stored at $4^{\circ} \mathrm{C}$ for the tests. The moisture content of tobacco was $12 \%$.

\subsection{Methods}

2.2.1. Direct Addition of Nitrate and Nitrite to Tobacco. The treatments included four levels of $\mathrm{NaNO}_{3}(10,20,30$, and $40 \mathrm{mg} / \mathrm{mL})$ and $\mathrm{NaNO}_{2}(5,10,15$, and $20 \mathrm{mg} / \mathrm{mL})$, which were from $10 \mathrm{~mL}$ solution each, equal to 73, 146, 219, and $292 \mathrm{mg}$ of $\mathrm{NO}_{3}{ }^{-}$and $33,67,100$, and $133 \mathrm{mg}$ of $\mathrm{NO}_{2}{ }^{-}$. The solutions were sprayed onto each of eight $20 \mathrm{~g}$ flue-cured tobacco samples. The samples were then placed to an ambient environment for 
air-drying. The moisture content of tobacco samples after airdrying was $13 \%$. Then the samples were stored in an airtight vacuum desiccator $\left(15 \mathrm{~cm}\right.$ diameter) at $45^{\circ} \mathrm{C}$ with relative humidity of $70 \%$ for $15 \mathrm{~d}$. The sample sprayed with the same volume of deionized water was used as the control. The moisture content of tobacco samples after treatment was $11.8 \%$.

2.2.2. Separating the Tobacco and Nitrate/Nitrite Sources in a Closed System under $45^{\circ} \mathrm{C}$ Storage Conditions. A vacuum desiccator with a porcelain plate was used to form a closed system in which tobacco cuts and added nitrate and nitrite could be separated during storage. Five $\mathrm{mL}$ of each aqueous solution of $\mathrm{NH}_{4} \mathrm{NO}_{3}, \mathrm{KNO}_{3}, \mathrm{NaNO}_{3}$, and $\mathrm{NaNO}_{2}$ at $1 \mathrm{~mol} / \mathrm{L}$ (equal to $310 \mathrm{mg}$ of $\mathrm{NO}_{3}{ }^{-}$and $230 \mathrm{mg}$ of $\mathrm{NO}_{2}{ }^{-}$) and $5 \mathrm{~mL}$ volume of deionized water (control) were sprayed onto the medical gauze pads $(5 \mathrm{~cm} \times 5 \mathrm{~cm})$. After air-drying, the sprayed gauzes were placed in the bottom of the vacuum desiccator together with each $20 \mathrm{~g}$ sample of flue-cured tobacco. The vacuum desiccators were then tightly closed and sealed with petroleum jelly. The containers were then placed into a chamber at a temperature of $45^{\circ} \mathrm{C}$ and a relative humidity of $70 \%$ and stored for $15 \mathrm{~d}$. The moisture content of tobacco samples after $45^{\circ} \mathrm{C}$ treatments was $11.1 \%$.

\subsubsection{Effect of Indirect Addition of Nitrate and Nitrite on Nitro-} gen Oxides Formation in a Closed System with Flue-Cured Tobacco. Eight treatments in this experiment were divided to two groups: Group I: (1) tobacco; (2) tobacco and $\mathrm{NaNO}_{3}$; (3) tobacco and $\mathrm{NaNO}_{3}+2.0 \mathrm{~g}$ activated carbon (AC); (4) tobacco and $\mathrm{NaNO}_{3}+10.0 \mathrm{~g} \mathrm{AC}$ and Group II: (1) tobacco; (2) tobacco and $\mathrm{NaNO}_{2}$; (3) tobacco and $\mathrm{NaNO}_{2}+2.0 \mathrm{~g} \mathrm{AC}$; (4) tobacco and $\mathrm{NaNO}_{2}+10.0 \mathrm{~g} \mathrm{AC}$. The amount of added $\mathrm{NaNO}_{3}$ or $\mathrm{NaNO}_{2}$ was $0.8 \mathrm{~g}$ and $0.4 \mathrm{~g}$ for treatments 2 to 4 (equal to $583 \mathrm{mg}$ of $\mathrm{NO}_{3}{ }^{-}$and $266 \mathrm{mg}$ of $\mathrm{NO}_{2}{ }^{-}$) in each group. The weight ratios of tobacco, $\mathrm{NO}_{3}{ }^{-}$, and $\mathrm{AC}$ were $68: 1: 3$ and $68: 1: 17$, respectively. And the weight ratios of tobacco, $\mathrm{NO}_{2}{ }^{-}$, and $A C$ were $150: 1: 7$ and $150: 1: 37$, respectively. $\mathrm{NaNO}_{3}$ and $\mathrm{NaNO}_{2}$ were dissolved in $5 \mathrm{~mL}$ deionized water and then sprayed onto the gauze pads. After air-drying, the gauze pads were placed on the bottom of the vacuum desiccator with $40 \mathrm{~g}$ sample of flue-cured tobacco leaf in each desiccator. AC sample was made from wood with the particle size being $75 \mu \mathrm{m}$, produced by Zhengzhou Tianhe Water Purification Material Co. Ltd. in Henan province. The surface area was $901.7 \mathrm{~m}^{2} / \mathrm{g}$, and the total pore volume was $0.518 \mathrm{~cm}^{3} / \mathrm{g}$ with the micropore, mesopore, and macroporous volume being $0.372 \mathrm{~cm}^{3} / \mathrm{g}, 0.129 \mathrm{~cm}^{3} / \mathrm{g}$, and $0.016 \mathrm{~cm}^{3} / \mathrm{g}$, respectively. AC was activated in $100^{\circ} \mathrm{C}$ oven for $30 \mathrm{~min}$, then was wrapped in a medical gauze, and suspended under the porcelain plate of the vacuum desiccator for the relevant treatments. All vacuum desiccators were tightly closed, sealed, and placed into a chamber at a temperature of $45^{\circ} \mathrm{C}$ and a relative humidity of $70 \%$ for $24 \mathrm{~h}$.

The AC used in the above experiments were taken out and then were placed in the new airtight desiccator, respectively. Two grams of AC was put into another container as control. All airtight desiccators were placed into a chamber at a temperature of $60^{\circ} \mathrm{C}$ and a relative humidity of $70 \%$ for $15 \mathrm{~min}$ and $90 \mathrm{~min}$.

\subsubsection{Effects of Activated Carbon (AC) on TSNAs Formation} in Flue-Cured Tobacco in Response to Nitrate and Nitrite Addition. Twelve treatments in this experiment were divided into two groups: Group I: (1) tobacco $\left(4^{\circ} \mathrm{C}\right)$; (2) tobacco (warm temperature control $45^{\circ} \mathrm{C}$ ); (3) tobacco and $\mathrm{NaNO}_{3}$ separately; (4) tobacco and $\mathrm{NaNO}_{3}+1.0 \mathrm{~g} \mathrm{AC}$ separately; (5) tobacco and $\mathrm{NaNO}_{3}+5.0 \mathrm{~g}$ AC separately; and (6) tobacco and $\mathrm{NaNO}_{3}+10.0 \mathrm{~g} \mathrm{AC}$ separately and Group II: (1) tobacco $\left(4^{\circ} \mathrm{C}\right.$ ); (2) tobacco (warm temperature control $45^{\circ} \mathrm{C}$ ); (3) tobacco and $\mathrm{NaNO}_{2}$ separately; (4) tobacco and $\mathrm{NaNO}_{2}$ $+1.0 \mathrm{~g}$ AC separately; (5) tobacco and $\mathrm{NaNO}_{2}+5.0 \mathrm{~g}$ AC separately; and (6) tobacco and $\mathrm{NaNO}_{2}+10.0 \mathrm{~g}$ AC separately. The amount of $\mathrm{NaNO}_{3}$ or $\mathrm{NaNO}_{2}$ added to each sample of treatments 3 to 6 was $0.3 \mathrm{~g}$ (equal to $219 \mathrm{mg}$ of $\mathrm{NO}_{3}{ }^{-}$ and $200 \mathrm{mg}$ of $\mathrm{NO}_{2}{ }^{-}$). The weight ratios of tobacco, $\mathrm{NO}_{3}{ }^{-}$, and AC were $91: 1: 4,91: 1: 22$, and $91: 1: 45$, respectively. And the weight ratios of tobacco, $\mathrm{NO}_{2}{ }^{-}$, and $\mathrm{AC}$ were $100: 1: 5$, $100: 1: 25$, and $100: 1: 50$, respectively. $\mathrm{NaNO}_{3} / \mathrm{NaNO}_{2}$ were dissolved in $5 \mathrm{~mL}$ deionized water and then were sprayed onto the gauze pads. After air-curing, the gauzes were placed on the bottom of the vacuum desiccators with $20 \mathrm{~g}$ sample of flue-cured tobacco leaf in each desiccator. All treatments were performed in the vacuum desiccator as described above. The activated AC also was used as described above. The vacuum desiccators were put into a chamber with a constant temperature of $45^{\circ} \mathrm{C}$ and a relative humidity of $70 \%$, respectively. The moisture content of cured tobacco samples after treatment was $11.6 \%$.

\subsection{Chemical Analyses}

2.3.1. TSNAs Measurements. In each experiment, tobacco samples were lyophilized, ground to powder, sieved through a $0.25 \mathrm{~mm}$ screen, and then measured for the content of NNN, NNK, NAT, and NAB. TSNAs contents were determined at the Beijing Cigarette Factory according to the method of SPELC-MS/MS [12, 17, 18].

2.3.2. Nitrate, Nitrite, and Alkaloid Measurements. $\mathrm{NO}_{3}-\mathrm{N}$ and $\mathrm{NO}_{2}-\mathrm{N}$ were quantified according to the method of Crutchfield and Grove [19]. The individual alkaloids were analyzed with a gas chromatograph as described by Jack and Bush [20]. Methyl tert-butyl ether was used as the extraction solvent with $\mathrm{N}$-hexadecane as the internal standard.

2.3.3. Nitrogen Oxides Analysis. The first step was diluting the standard gas with a dynamic gas calibrator (Model $146 \mathrm{i}$, Thermo Scientific, USA EPA) to give a concentration within the operational range of the instrument. The high purity nitric oxide (NO) and nitrogen dioxide $\left(\mathrm{NO}_{2}\right)$ standards in $\mathrm{N}_{2}$ (component content: $69.8 \mathrm{ppm}$, gas sample number: L120911099, National Institute of Metrology/National Standard Material Research Center, Beijing, China) were configured into nitrogen oxides gas of a low concentration (1 ppm) by $146 \mathrm{i}$ calibrator. It was necessary to modify the original 


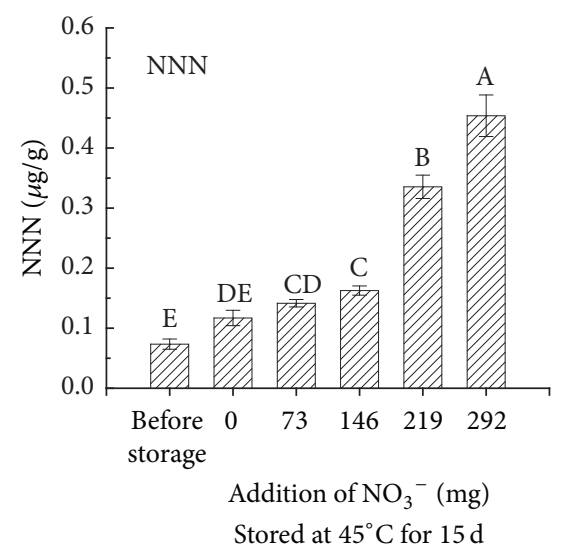

(a)

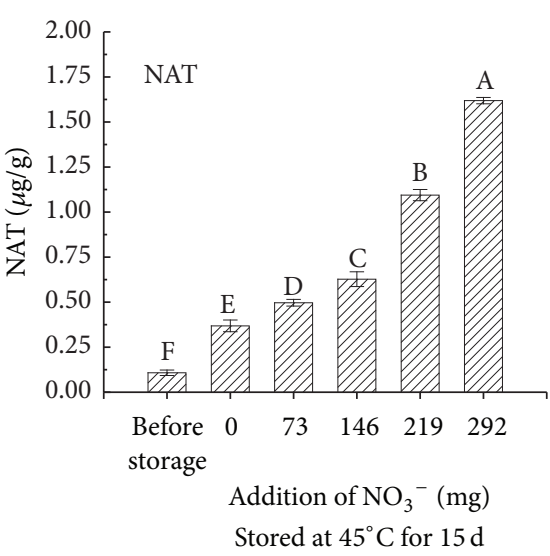

(b)

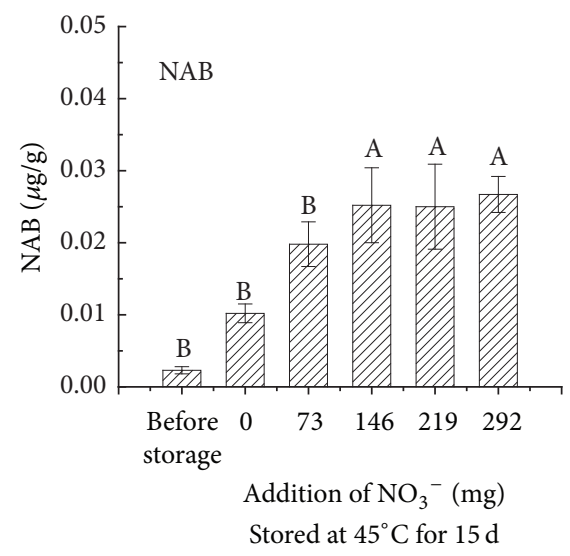

(c)

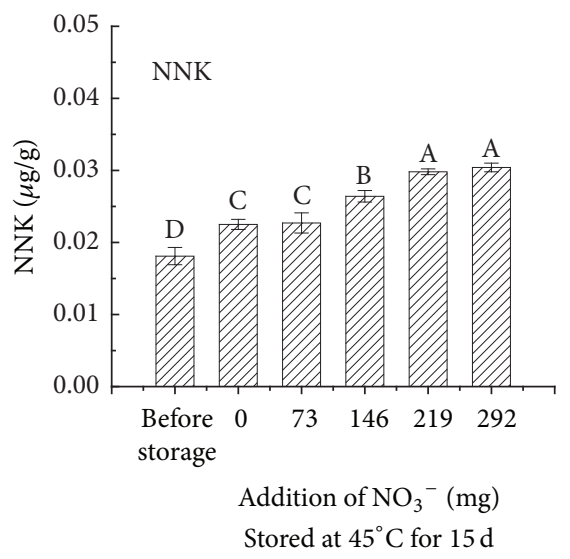

(d)

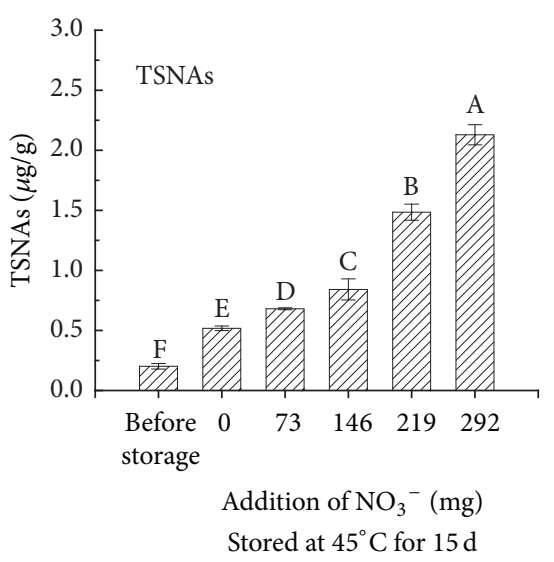

(e)

FIGURE 3: Effects of added nitrate on TSNAs formation in flue-cured tobacco stored at $45^{\circ} \mathrm{C}$ for $15 \mathrm{~d}$. Note. For all experiments, each value represents the mean of three independent samples. Uppercase letters indicate significant differences between the treatments at $P<0.05$.

procedure by configuring the standard gas again if the levels of NOx exceeded the limit of detection. The NO and NOx in the air were defaulted to the zero point by the instrument.

After experiment, the airtight vacuum desiccators were taken out and then connected with a vacuum pump (DOAP504-BN, GAST Manufacturing, A Unit of Idex Corporation, MI, USA) to extract the gas into a gas collecting bag. After $25 \mathrm{~s}$, the gas bag was pulled out and connected with the $\mathrm{NO}-\mathrm{NO}_{2}-\mathrm{NO}_{X}$ analyzer (Model 42i, Thermo Scientific, USA EPA, Reference method RFNA-1289-074) for NOx analysis by chemiluminescence detection.

2.4. Statistical Analyses. Analysis of variance (ANOVA) and least significant difference (LSD) of TSNAs and NOx values were performed at the 0.05 level of significance. Data were statistically analyzed with SPSS 20.0. Figures were drawn with Origin 8.5. All treatments were randomly designed in triplicate.

\section{Results and Discussion}

3.1. Effect of Nitrate Concentration on TSNAs Formation in Flue-Cured Tobacco. The mean contents of nicotine, nornicotine, anabasine, and anatabine of tobacco used in this experiment were $19.8,1.2,0.3$, and $1.5 \mathrm{mg} / \mathrm{g}$, respectively, and the $\mathrm{NO}_{3}-\mathrm{N}$ and $\mathrm{NO}_{2}-\mathrm{N}$ content were correspondingly $119 \mu \mathrm{g} / \mathrm{g}$ and $10 \mu \mathrm{g} / \mathrm{g}$. With the increasing amount of $\mathrm{NO}_{3}{ }^{-}$ added, both individual and total TSNAs contents increased significantly (Figure 3). After the addition of $0.4 \mathrm{~g} \mathrm{NaNO}_{3}$ (equal to $292 \mathrm{mg}$ of $\mathrm{NO}_{3}{ }^{-}$), the NAT and total TSNAs contents increased by $340 \%$ and $311 \%$, respectively, in comparison with the control.

No significant change of NNN was observed in the tobacco samples when less than $0.2 \mathrm{~g}$ of $\mathrm{NaNO}_{3}(146 \mathrm{mg}$ of $\mathrm{NO}_{3}{ }^{-}$) was added. However, when the amount of $\mathrm{NO}_{3}{ }^{-}$ added increased to $219 \mathrm{mg}\left(0.3 \mathrm{~g} \mathrm{NaNO}_{3}\right)$, the $\mathrm{NNN}$ content was approximately double that of $0.2 \mathrm{~g} \mathrm{NaNO}_{3}$ addition. Although the NAB content was the lowest of the four individual TSNAs, a significant increase in NAB content occurred as a result of the addition of $\mathrm{NaNO}_{3}$ reached to $0.2 \mathrm{~g}$. The NNK content also increased significantly as nitrate addition increased.

3.2. Effect of Nitrite Concentration on TSNAs Formation in Flue-Cured Tobacco. Table 1 shows that as the concentration of added $\mathrm{NO}_{2}{ }^{-}$increased, the individual and total TSNAs contents showed rapid and dramatic increases, and the relative increments were greater for the samples with greater 


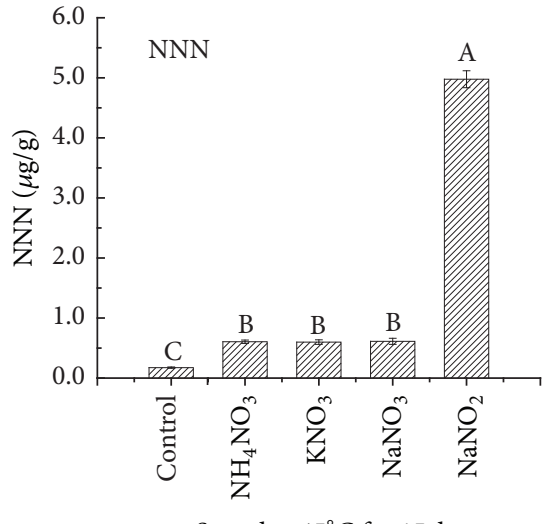

Stored at $45^{\circ} \mathrm{C}$ for $15 \mathrm{~d}$

(a)

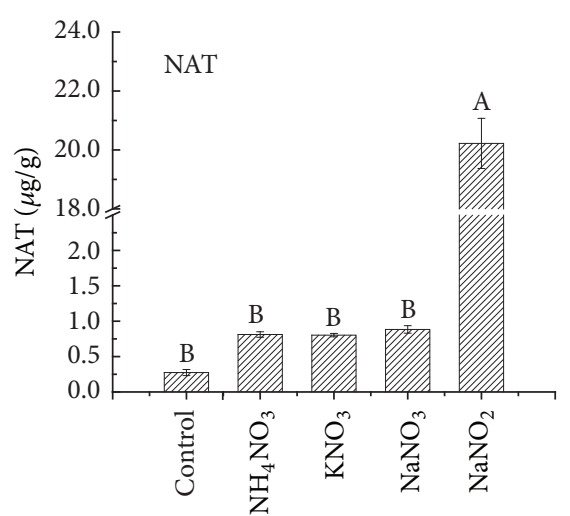

Stored at $45^{\circ} \mathrm{C}$ for $15 \mathrm{~d}$

(b)

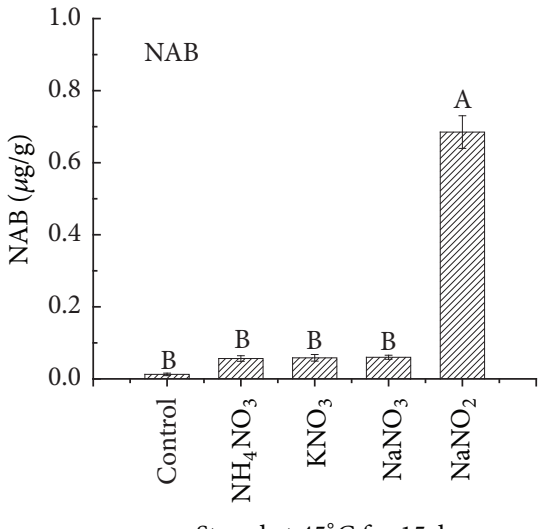

(c)

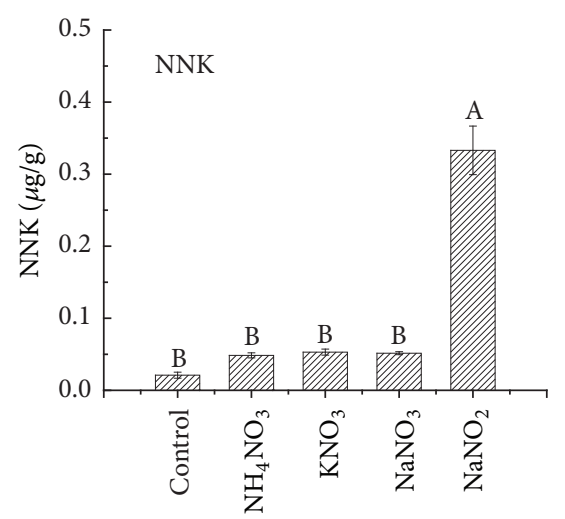

Stored at $45^{\circ} \mathrm{C}$ for $15 \mathrm{~d}$

(d)

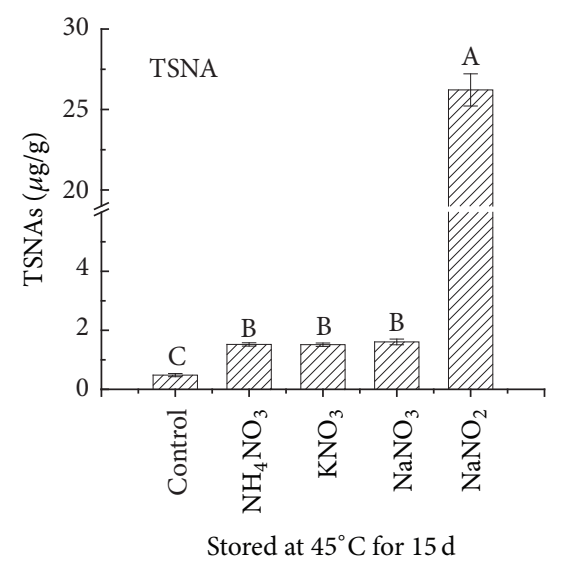

(e)

FIGURE 4: Effects of indirect addition of three nitrate compounds and sodium nitrite on TSNAs formation in flue-cured tobacco during warm

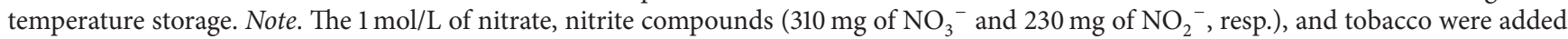
separately in the closed vessel which was then stored at $45^{\circ} \mathrm{C}$ for $15 \mathrm{~d}$. Uppercase letters indicate significant differences between the treatments at $P<0.05$.

amounts of added $\mathrm{NO}_{2}{ }^{-}$. When tobacco samples were treated with $133 \mathrm{mg}$ of $\mathrm{NO}_{2}^{-}\left(0.2 \mathrm{~g}\right.$ of $\left.\mathrm{NaNO}_{2}\right)$, total TSNAs content was $117 \mu \mathrm{g} / \mathrm{g}$, at a $207 \%$ increment compared with the control $(0.56 \mu \mathrm{g} / \mathrm{g})$. For the individual TSNA, levels of NNN, NNK, NAT, and NAB showed 257-, 38-, 203-, and 110-fold increases, respectively. The results showed that $\mathrm{NO}_{2}{ }^{-}$was more effective in promoting TSNAs formation in the cured leaf than $\mathrm{NO}_{3}{ }^{-}$ during warm temperature storage.

The higher TSNAs levels in burley tobacco are partly due to the relatively higher levels of TSNAs precursors, such as alkaloids and oxide of nitrogen, that are present in the leaf tissue [21-23]. It is reported that nitrite which is derived from the bacterially mediated reduction of nitrate is considered to be the limiting factor in TSNAs formation in air-cured tobacco during air-curing $[6,24]$. In this research, the addition of nitrate and nitrite in flue-cured tobacco to the levels which are equivalent to those in burley tobacco can increase the TSNAs concentration comparable to burley tobacco especially coupled with warm temperature. Results indicated that the great amount of nitrosating species available is a major contributor to the formation of TSNAs observed in cured tobacco during storage.

3.3. Effects of Indirect Addition of Nitrate/Nitrite on TSNA Formation in Flue-Cured Tobacco during Warm Temperature Storage. TSNAs contents increased as the storage temperature increased $[15,16]$, and the abundance of nitrite and nitrate could be a major contributor. To clarify how nitrate or nitrite affects the formation of TSNAs under warm temperature, indirect addition of nitrate or nitrite experiments was carried out.

After tobacco leaf treated with $1 \mathrm{~mol} / \mathrm{L} \mathrm{NaNO}_{2}$, total TSNAs content increased almost by 54 times compared with that in the control sample (Figure 4). When tobacco leaf is placed separately with gauze pad containing $310 \mathrm{mg}$ nitrate, obvious increases were observed both in individual and 
TABLE 1: Effects of added nitrite on TSNAs formation in flue-cured tobacco stored at $45^{\circ} \mathrm{C}$ for $15 \mathrm{~d}$.

\begin{tabular}{lcccccc}
\hline Storage conditions & Addition of $\mathrm{NO}_{2}^{-}(\mathrm{mg})$ & $\mathrm{NNN}(\mu \mathrm{g} / \mathrm{g})$ & $\mathrm{NAT}(\mu \mathrm{g} / \mathrm{g})$ & $\mathrm{NAB}(\mu \mathrm{g} / \mathrm{g})$ & $\mathrm{NNK}(\mu \mathrm{g} / \mathrm{g})$ & Total TSNAs $(\mu \mathrm{g} / \mathrm{g})$ \\
\hline Before storage & 0 & $0.08 \pm 0.01^{\mathrm{E}}$ & $0.11 \pm 0.01^{\mathrm{E}}$ & $0.004 \pm 0.00^{\mathrm{E}}$ & $0.03 \pm 0.00^{\mathrm{D}}$ & $0.22 \pm 0.00^{\mathrm{E}}$ \\
& 0 & $0.13 \pm 0.01^{\mathrm{E}}$ & $0.39 \pm 0.02^{\mathrm{E}}$ & $0.02 \pm 0.00^{\mathrm{E}}$ & $0.03 \pm 0.01^{\mathrm{D}}$ & $0.56 \pm 0.03^{\mathrm{E}}$ \\
& 33 & $5.85 \pm 0.28^{\mathrm{D}}$ & $18.97 \pm 0.31^{\mathrm{D}}$ & $0.31 \pm 0.03^{\mathrm{D}}$ & $0.09 \pm 0.01^{\mathrm{CD}}$ & $25.22 \pm 0.07^{\mathrm{D}}$ \\
$45^{\circ} \mathrm{C}$ for 15 d & 67 & $12.85 \pm 0.88^{\mathrm{C}}$ & $41.73 \pm 1.95^{\mathrm{C}}$ & $0.77 \pm 0.06^{\mathrm{C}}$ & $0.23 \pm 0.03^{\mathrm{C}}$ & $55.57 \pm 2.74^{\mathrm{C}}$ \\
& 100 & $19.22 \pm 1.13^{\mathrm{B}}$ & $51.96 \pm 1.54^{\mathrm{B}}$ & $1.15 \pm 0.15^{\mathrm{B}}$ & $0.66 \pm 0.09^{\mathrm{B}}$ & $72.99 \pm 2.44^{\mathrm{B}}$ \\
& 133 & $33.66 \pm 2.18^{\mathrm{A}}$ & $79.68 \pm 0.96^{\mathrm{A}}$ & $2.25 \pm 0.23^{\mathrm{A}}$ & $1.21 \pm 0.16^{\mathrm{A}}$ & $116.80 \pm 3.53^{\mathrm{A}}$ \\
\hline
\end{tabular}

Note. Each value represents the mean of three independent samples, and uppercase letters indicate significant differences between the treatments at $P<0.05$.

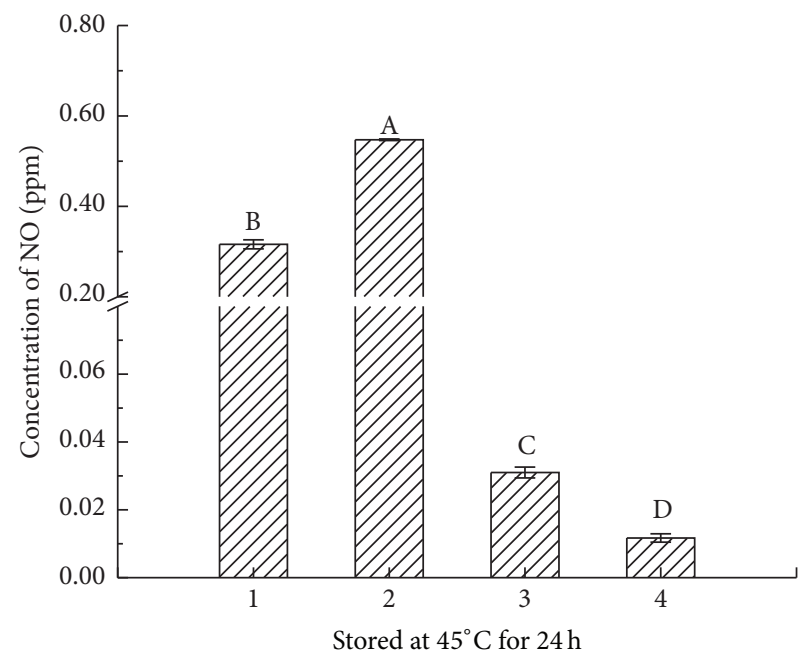

(a)

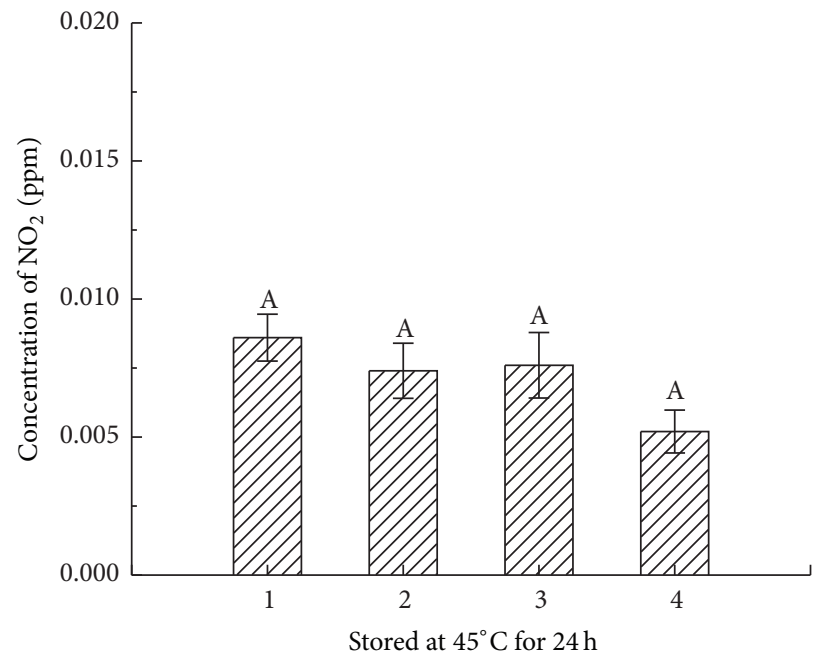

(b)

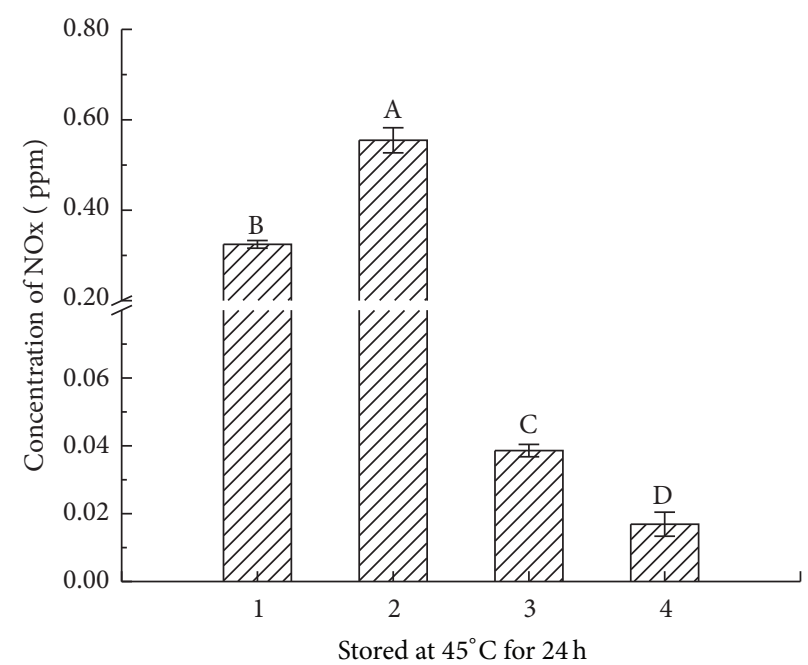

(c)

FIGURE 5: Effect of indirect addition of nitrate and activated carbon (AC) on nitrogen oxides formation in a closed system with flue-cured tobacco. Note. (1) tobacco, (2) tobacco $+\mathrm{NaNO}_{3}$, (3) tobacco $+\mathrm{NaNO}_{3}+\mathrm{AC} 2.0 \mathrm{~g}$, and (4) tobacco $+\mathrm{NaNO}_{3}+\mathrm{AC} 10.0 \mathrm{~g}, 40 \mathrm{~g}$ of flue-cured tobacco, and $0.8 \mathrm{~g} \mathrm{NaNO}_{3}\left(583 \mathrm{mg}\right.$ of $\left.\mathrm{NO}_{3}{ }^{-}\right)$. The $\mathrm{NO}_{3}{ }^{-}, \mathrm{AC}$, and tobacco were added separately in the vacuum desiccators stored at $45^{\circ} \mathrm{C}$ for $24 \mathrm{~h}$. Uppercase letters indicate significant differences between the treatments at $P<0.05$.

in total TSNA content compared with the control. Data presented here suggested that even though the tobacco sample is placed separately with nitrate or nitrite, TSNA content in tobacco also increased. The formation of TSNAs in storage triggered by nitrate and nitrite is likely a gas phase reaction.
3.4. Effect of Indirect Addition of Nitrate/Nitrite on NOx Formation in a Closed System with Flue-Cured Tobacco. Fluecured tobacco leaves could generate trace concentrations of NOx under $45^{\circ} \mathrm{C}$ after $24 \mathrm{~h}$ treatment (Figures 5 and 6). As a main component, $\mathrm{NO}$ accounted for more than $95 \%$ of the NOx produced from the tobacco sample. As $0.8 \mathrm{~g}$ of 


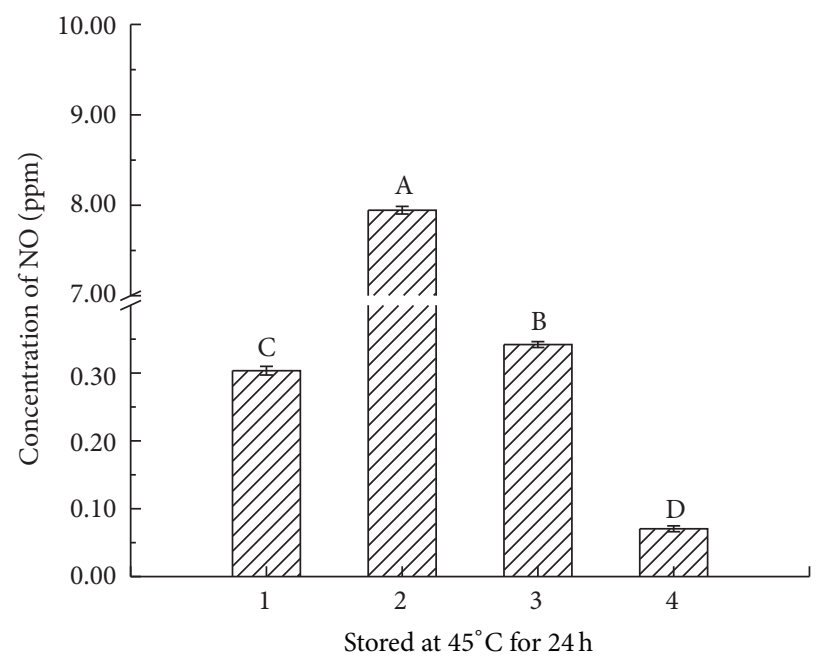

(a)

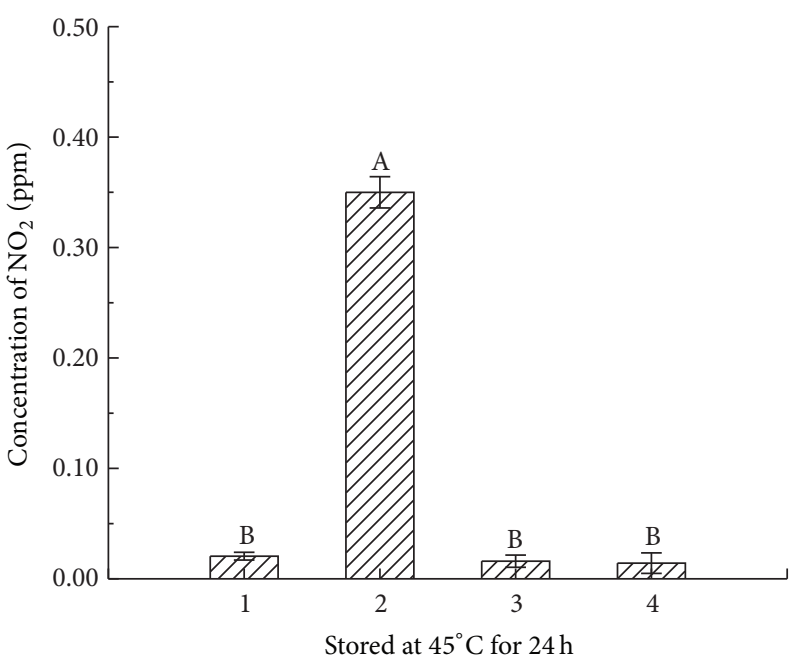

(b)

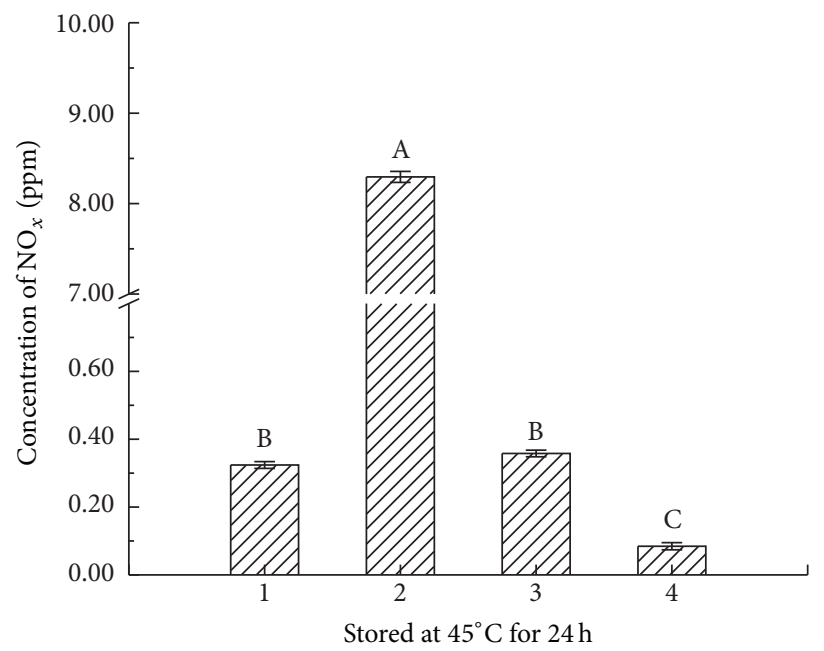

(c)

FIGURE 6: Effect of indirect addition of nitrite and activated carbon (AC) on nitrogen oxides formation in a closed system with flue-cured tobacco. Note. (1) tobacco, (2) tobacco $+\mathrm{NaNO}_{2}$, (3) tobacco $+\mathrm{NaNO}_{2}+\mathrm{AC} 2.0 \mathrm{~g}$, and (4) tobacco $+\mathrm{NaNO}_{2}+\mathrm{AC} 10.0 \mathrm{~g}, 40 \mathrm{~g}$ of flue-cured tobacco, and $0.4 \mathrm{~g} \mathrm{NaNO}_{2}\left(266 \mathrm{mg}\right.$ of $\left.\mathrm{NO}_{2}{ }^{-}\right)$. The $\mathrm{NO}_{2}{ }^{-}, \mathrm{AC}$, and tobacco were added separately in vacuum desiccators stored at $45^{\circ} \mathrm{C}$ for $24 \mathrm{~h}$. Uppercase letters indicate significant differences between the treatments at $P<0.05$.

$\mathrm{NaNO}_{3}$ (equal to $583 \mathrm{mg}$ of nitrate) was added in the vacuum desiccator, the concentration of $\mathrm{NO}$ and NOx increased significantly $(P<0.05)$; NOx reached $0.6 \mathrm{ppm}$ (Figure $5(\mathrm{c})$ ). When $0.4 \mathrm{~g}$ of $\mathrm{NaNO}_{2}$ (equal to $266 \mathrm{mg}$ of nitrite) was added, NOx concentrations in the desiccator dramatically increased to $8.3 \mathrm{ppm}$, which was 24.6 -fold greater than the control (Figure 6(c)).

It is interesting that when $2 \mathrm{~g}$ of $\mathrm{AC}$ was added to the system (the weight ratio of tobacco, $\mathrm{NO}_{3}{ }^{-}$, and $\mathrm{AC}$ is $68: 1: 3$; the weight ratio of tobacco, $\mathrm{NO}_{2}{ }^{-}$, and $\mathrm{AC}$ is $\left.150: 1: 7\right)$, a $97 \%$ decrease of NOx level was observed in comparison to the added nitrate treatment (Figure 5(c)), and almost $7.9 \mathrm{ppm}$ of NOx were adsorbed by AC (Figure 6(c)). Meanwhile, similar adsorption effects were observed for NO. The concentration of NO and NOx decreased significantly $(P<0.05)$ as the addition of AC increased, indicating strong adsorption for NOx generated from nitrate and nitrite by AC.
Table 2 presents the desorption rate of NOx from the AC samples which were used for the adsorption experiments and were significantly higher than those from control group. The desorption rates of NOx and NO were obviously increased with the prolonging of treating time and the increase of NOx adsorption observed in Figures 5 and 6. Results indicated that NOx were indeed adsorbed by AC. As the weight ratio of tobacco, $\mathrm{NO}_{2}{ }^{-}$, and $\mathrm{AC}$ is $150: 1: 7, \mathrm{NOx}$ decreased by $7.9 \mathrm{ppm}$ (Figure 6(c)); at the same time $0.632 \mathrm{ppm}$ of NOx was desorbed by the AC after treatment at $60^{\circ} \mathrm{C}$ for $90 \mathrm{~min}$. Since the desorption rate of $\mathrm{NOx}$ in $\mathrm{AC}$ has close relationship with the temperature and time [25], further research is needed to determine the effect of desorbing temperature and time on the desorption rate of NOx adsorbed by AC.

During flue-curing process, direct-fired systems allow combustion products, specifically NOx, to mix with the air and expose the green tobacco leaves to these gases [26]. The 
TABLE 2: The desorption rate of $\mathrm{NOx}$ at $60^{\circ} \mathrm{C}$ for different time.

\begin{tabular}{|c|c|c|c|c|c|}
\hline \multirow{2}{*}{\multicolumn{2}{|c|}{ Treatment }} & \multicolumn{2}{|c|}{ NO (ppm) } & \multicolumn{2}{|c|}{ NOx (ppm) } \\
\hline & & $15 \mathrm{~min}$ & $90 \mathrm{~min}$ & $15 \mathrm{~min}$ & $90 \mathrm{~min}$ \\
\hline \multicolumn{2}{|c|}{ AC (Control) } & $0.0094^{\mathrm{C}}$ & $0.0249^{\mathrm{C}}$ & $0.0203^{\mathrm{B}}$ & $0.0486^{\mathrm{B}}$ \\
\hline \multirow{2}{*}{ AC used in Figure 5} & Treatment 3 (2 g AC) & $0.0200^{\mathrm{B}}$ & $0.0466^{\mathrm{B}}$ & $0.0220^{\mathrm{B}}$ & $0.0505^{\mathrm{B}}$ \\
\hline & Treatment $4(10 \mathrm{~g} \mathrm{AC})$ & $0.0216^{\mathrm{B}}$ & $0.0471^{\mathrm{B}}$ & $0.0244^{\mathrm{B}}$ & $0.0511^{\mathrm{B}}$ \\
\hline \multirow{2}{*}{ AC used in Figure 6} & Treatment 3 (2 g AC) & $0.0732^{\mathrm{A}}$ & $0.6200^{\mathrm{A}}$ & $0.0864^{\mathrm{A}}$ & $0.6320^{\mathrm{A}}$ \\
\hline & Treatment 4 (10 g AC) & $0.0740^{\mathrm{A}}$ & $0.6302^{\mathrm{A}}$ & $0.0887^{\mathrm{A}}$ & $0.6435^{\mathrm{A}}$ \\
\hline
\end{tabular}

Note. Each value represents the mean of three independent samples, and uppercase letters indicate significant differences between the treatments at $P<0.05$.

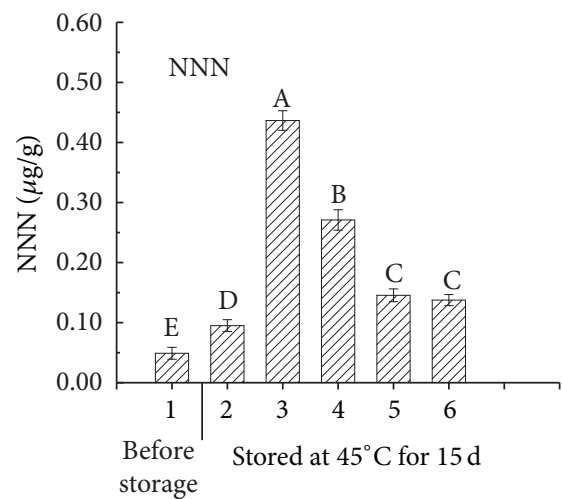

(a)

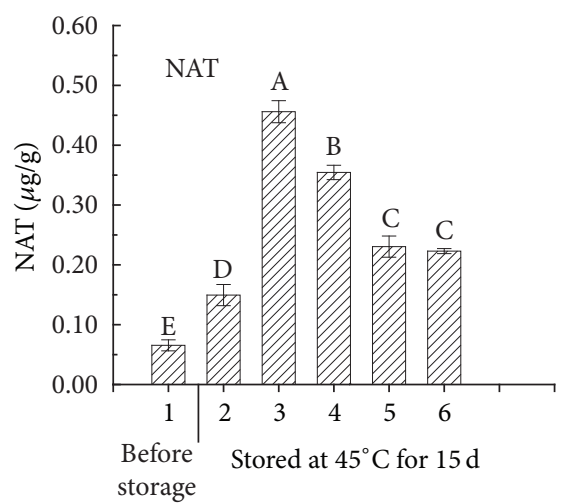

(b)

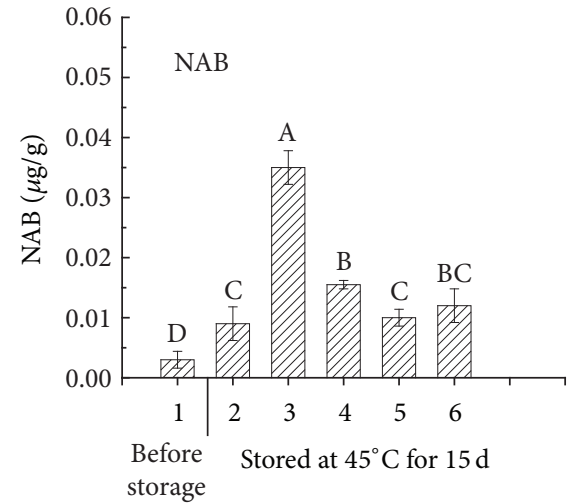

(c)

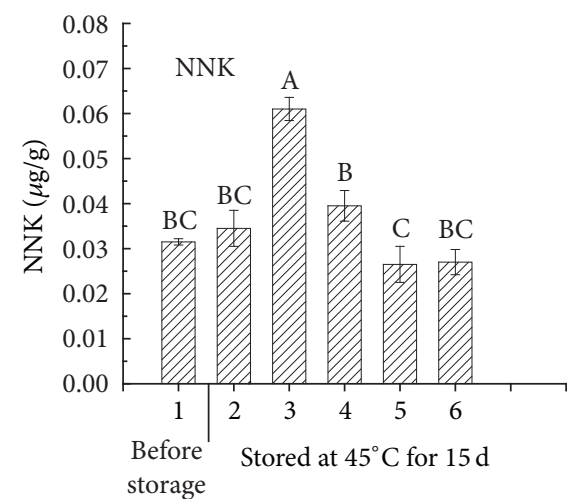

(d)

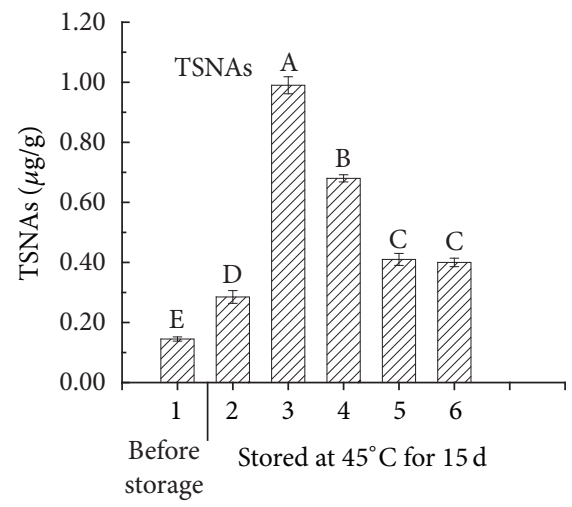

(e)

Figure 7: Effect of activated carbon (AC) on TSNAs formation in flue-cured tobacco in response to nitrate addition. Note. (1) tobacco (before storage, $4^{\circ} \mathrm{C}$ ), (2) tobacco, (3) tobacco $+\mathrm{NaNO}_{3}$, (4) tobacco $+\mathrm{NaNO}_{3}+\mathrm{AC} 1.0 \mathrm{~g}$, (5) tobacco $+\mathrm{NaNO}_{3}+\mathrm{AC} 5.0 \mathrm{~g}$, and (6) tobacco $+\mathrm{NaNO}_{3}$ $+\mathrm{AC} 10.0 \mathrm{~g}, 20 \mathrm{~g}$ of flue-cured tobacco, and $0.3 \mathrm{~g} \mathrm{NaNO}_{3}\left(219 \mathrm{mg}\right.$ of $\left.\mathrm{NO}_{3}{ }^{-}\right)$. The $\mathrm{NO}_{3}{ }^{-}, \mathrm{AC}$, and tobacco were added separately in the vacuum desiccators stored at $45^{\circ} \mathrm{C}$ for $15 \mathrm{~d}$. Uppercase letters indicate significant differences between the treatments at $P<0.05$.

previous research showed that TSNAs may be formed by nitrosation via the elevated levels of NOx in the air surrounding the leaves during the curing process [27]. However, there were few reports about the relationship between NOx and TSNAs during storage process. Data in Figure 4 suggested that TSNAs in storage is likely a gas phase reaction. This result showed that $\mathrm{NOx}$ can be generated from $\mathrm{NO}_{2}-\mathrm{N}$ and $\mathrm{NO}_{3}-\mathrm{N}$ under $45^{\circ} \mathrm{C}$ after $24 \mathrm{~h}$. Nitrite was more effective than nitrate in the production of NOx which in turn would probably promote the formation of TSNAs.
3.5. Effect of AC on TSNAs Formation in Flue-Cured Tobacco in Response to Nitrate and Nitrite Added. Having a very porous structure and special surface properties, AC has been used to trap TSNAs in tobacco solution [28,29]. Lin et al. [30] reported that AC made from coconut shells exhibited a high affinity for TSNAs. The impregnated sorbent ZnAC can remove $73 \%$ of the TSNAs in solution, offering a cost-effective candidate for industrial applications [29].

As shown in Figures 7(e) and 8(e), total TSNAs content in tobacco incubated separately with $\mathrm{NO}_{2}{ }^{-}$(treatment 3 ) at 


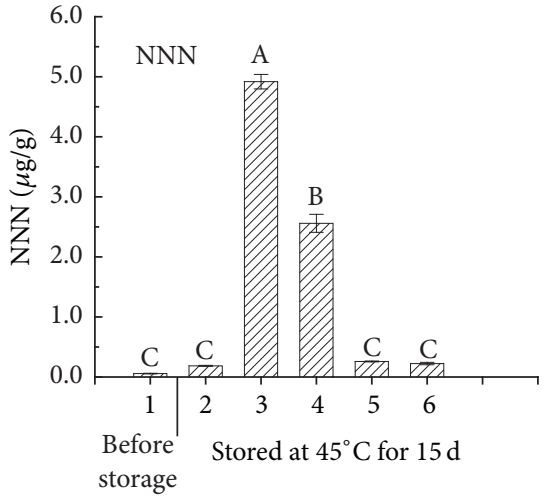

(a)

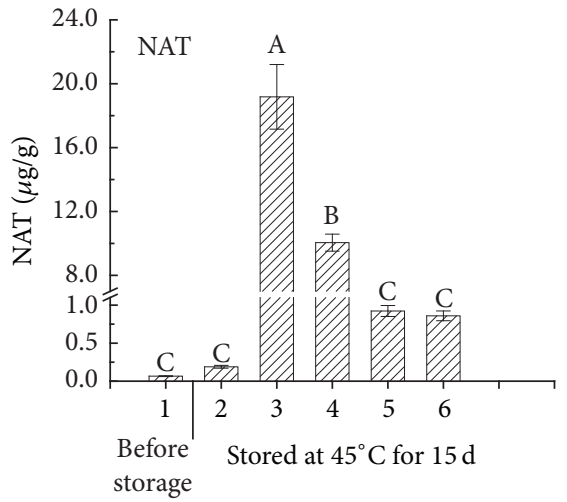

(b)

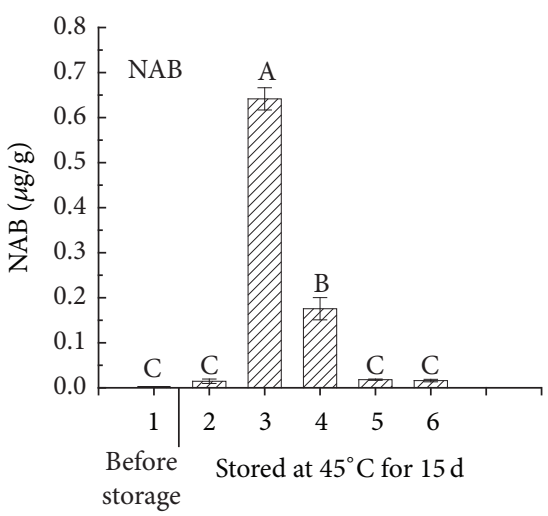

(c)

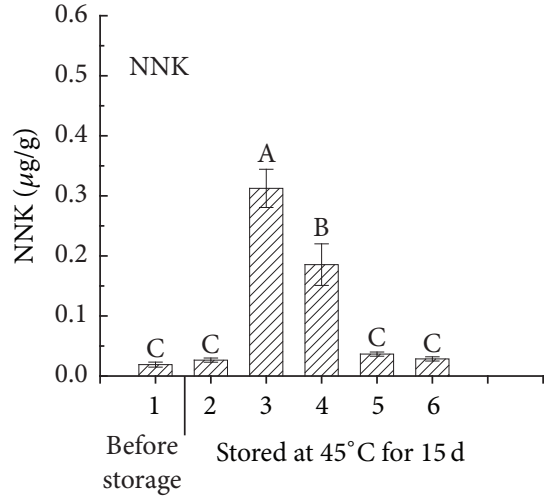

(d)

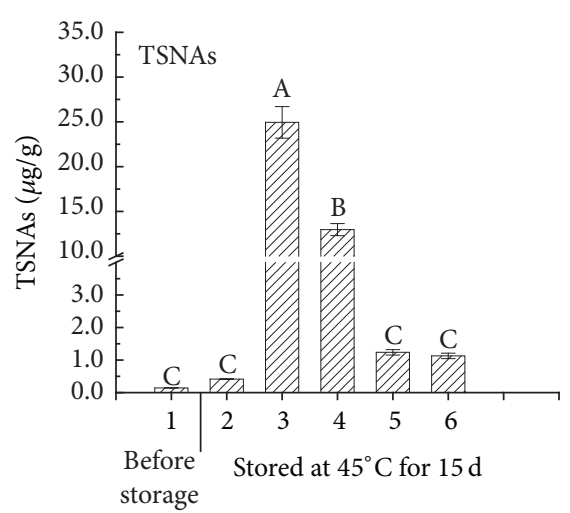

(e)

FIGURE 8: Effect of activated carbon (AC) on TSNAs formation in flue-cured tobacco in response to nitrite addition. Note. (1) tobacco (before storage, $4^{\circ} \mathrm{C}$ ), (2) tobacco, (3) tobacco $+\mathrm{NaNO}_{2}$, (4) tobacco $+\mathrm{NaNO}_{2}+\mathrm{AC} 1.0 \mathrm{~g}$, (5) tobacco $+\mathrm{NaNO}_{2}+\mathrm{AC} 5.0 \mathrm{~g}$, and (6) tobacco $+\mathrm{NaNO}_{2}$ $+\mathrm{AC} 10.0 \mathrm{~g}, 20 \mathrm{~g}$ of flue-cured tobacco, and $0.3 \mathrm{~g} \mathrm{NaNO}_{2}\left(200 \mathrm{mg}\right.$ of $\left.\mathrm{NO}_{2}{ }^{-}\right)$. The $\mathrm{NO}_{2}{ }^{-}, \mathrm{AC}$, and tobacco were added separately in the vacuum desiccators stored at $45^{\circ} \mathrm{C}$ for $15 \mathrm{~d}$. Uppercase letters indicate significant differences between the treatments at $P<0.05$.

$45^{\circ} \mathrm{C}$ increased markedly to $25 \mu \mathrm{g} / \mathrm{g}$, a 59 -fold increase over the control (treatment 2). By treating tobacco with $\mathrm{NO}_{3}{ }^{-}$, however, total TSNAs increased to $1 \mu \mathrm{g} / \mathrm{g}$, also significantly higher than the control. The huge difference of TSNAs content between tobacco treated with $\mathrm{NO}_{2}{ }^{-}$and $\mathrm{NO}_{3}{ }^{-}$could be attributed to the high concentration of $\mathrm{NOx}$ which were emitted from $\mathrm{NO}_{2}{ }^{-}$under the same condition.

However, after adding $1 \mathrm{~g}$ of $\mathrm{AC}$ to the separating system of tobacco and $\mathrm{NO}_{2}{ }^{-}$, the weight ratio of tobacco, $\mathrm{NO}_{2}{ }^{-}$, and AC was $100: 1: 5$, both individual and total TSNAs contents of tobacco decreased markedly, with total TSNAs content decreasing to $13 \mu \mathrm{g} / \mathrm{g}, 48 \%$ lower than in treatment 3 , and NNN, NAT, NAB, and NNK decreasing by $47.9 \%$, $47.6 \%, 67.3 \%$ and $41 \%$, respectively. When the addition of AC increased to $5 \mathrm{~g}$, the weight ratio of tobacco, $\mathrm{NO}_{2}{ }^{-}$and $\mathrm{AC}$ reached to $100: 1: 25$, total TSNAs levels further decreased to $1.2 \mu \mathrm{g} / \mathrm{g}$, indicating a crucial role of AC in inhibiting TSNAs formation by adsorbing the $\mathrm{NOx}$ generated from $\mathrm{NO}_{2}-\mathrm{N}$ and $\mathrm{NO}_{3}-\mathrm{N}$. The results also showed no significant differences in reducing TSNAs levels by increasing AC usage greater than $5 \mathrm{~g}$ (Figures 7 and 8). The maximum inhibitory effect of $\mathrm{AC}$ on TSNAs formation occurred at an $\mathrm{AC} / \mathrm{NO}_{2}{ }^{-}$ratio of $25 / 1$. The above results indicated that $\mathrm{AC}$ may have the potential to be used as adsorbent agent to reduce TSNAs formation during tobacco leaf storage. Our results strongly support the theory that TSNAs formation in storage is a gas phase reaction, and the NOx which is produced from nitrate and nitrite could intermediate the TSNAs formation during warm temperature postcured storage of tobacco. Since NOx can be produced from nitrate and nitrite under warm temperature in a short period, it can readily react with alkaloids to form TSNAs. This result also explained why the most rapid increase in TSNAs occurred during the warm temperature season [16].

Decreasing NOx level by AC adsorption significantly reduced TSNAs formation of tobacco which indicated that the removal of NOx from storage environment could be an effective way to inhibit TSNAs formation in storing tobacco leaf. Therefore, controlling the storage environment and scavenging gaseous nitrosation agents would be crucial to reduce or inhibit TSNAs formation during leaf storage.

\section{Conclusion}

The results proved that TSNAs are derived from a gas/solid phase nitrosation reaction between $\mathrm{NOx}$ and alkaloids during 
storage. Nitrogen oxides produced from nitrate and nitrite are responsible for the formation of TSNAs during storage under warm temperature. Presence of activated carbon in the tobacco storage containers effectively inhibited the TSNAs formation due to the adsorption of $\mathrm{NOx}$ on the activated carbon.

\section{Conflicts of Interest}

The authors declare that there are no conflicts of interest regarding the publication of this paper.

\section{Authors' Contributions}

Jun Wang and Huijuan Yang contributed equally to this work and should be considered co-first authors.

\section{References}

[1] J. D. Adams, S. J. Lee, N. Vinchkoski, A. Castonguay, and D. Hoffmann, "On the formation of the tobacco-specific carcinogen 4-(methylnitrosamino)-1-(3-pyridyl)-1-butanone during smoking," Cancer Letters, vol. 17, no. 3, pp. 339-346, 1983.

[2] D. Hoffmann, M. Dong, and S. S. Hecht, "Origin in tobacco smoke of N/-nitrosonornicotine, a tobacco-specific carcinogen: brief communication," Journal of the National Cancer Institute, vol. 58, no. 6, pp. 1841-1844, 1977.

[3] P. C. Gupta, P. R. Murti, and R. B. Bhonsle, "Epidemiology of cancer by tobacco products and the significance of TSNA," Critical Reviews in Toxicology, vol. 26, no. 2, pp. 183-198, 1996.

[4] S. S. Hecht, "Biochemistry, biology, and carcinogenicity of tobacco-specific N- nitrosamines," Chemical Research in Toxicology, vol. 11, no. 6, pp. 559-603, 1998.

[5] H. Shi and J. Zhang, "The significant of alkaloids," in Tobacco Alkaloids, vol. 1st, p. 14, China Agriculture Press, Beijing, China, 2004.

[6] L. P. Bush, M. Cui, H. Shi et al., "Formation of tobacco specific nitrosamines in air-cured tobacco," Recent Advances in Tobacco Science, vol. 27, pp. 23-46, 2001.

[7] M. V. Djordjevic, S. L. Gay, L. P. Bush, and J. F. Chaplin, "Tobacco-specific nitrosamine accumulation and distribution in flue-cured tobacco alkaloid isolines," Journal of Agricultural and Food Chemistry, vol. 37, no. 3, pp. 752-758, 1989.

[8] I. Stepanov, A. Knezevich, L. Zhang, C. H. Watson, D. K. Hatsukami, and S. S. Hecht, "Carcinogenic tobacco-specific Nnitrosamines in US cigarettes: three decades of remarkable neglect by the tobacco industry," Tobacco Control, vol. 21, no. 1, pp. 44-48, 2011.

[9] S.-C. Shen, K.-C. Tseng, and J. S.-B. Wu, "An analysis of Maillard reaction products in ethanolic glucose-glycine solution," Food Chemistry, vol. 102, no. 1, pp. 281-287, 2007.

[10] M. Cui, The source and the regulation of nitrogen oxide production for tobacco-specific nitrosamine formation during air-curing tobacco [Ph.D. thesis], University of Kentucky, Lexington, Ky, USA, 1998.

[11] H. R. Burton, N. K. Dye, and L. P. Bush, "Relationship between TSNA and nitrite from different air-cured tobacco varieties," Journal of Agricultural and Food Chemistry, vol. 42, pp. 20072011, 1994.
[12] X. Wei, X. Deng, D. Cai et al., "Decreased tobacco-specific nitrosamines by microbial treatment with Bacillus amyloliquefaciens DA9 during the air-curing process of burley tobacco," Journal of Agricultural and Food Chemistry, vol. 62, no. 52, pp. 12701-12706, 2014

[13] J. L. Verrier, A. Wiernik, M. Staaf, J. 1. Cadilhac, M. Onillon, and B. Vidal, "The influence of post-curing of burley tobacco and dark air-cured tobacco on TSNA and nitrite levels," in Proceedings of the CORESTA Congress, Shanghai, China, November 2008.

[14] R. M. Jackisch and J. H. Rovedder, "Burley tobacco postcuring management and its effect in the nitrosamine amount," in Proceedings of the CORESTA Joint Study Group Meeting, Krakow, Poland, October 2007, https://www.coresta.org/abstracts/ burley-tobacco-post-curing-management-and-its-effect-nitrosamine-amount-1525.html.

[15] H. Saito, M. Miyazaki, and J. Miki, "Role of nitrogen oxides in tobacco-specific nitrosamine formation in burley tobacco," in Proceedings of the 2006 CORESTA Congress, Paris, France, October 2006, https://www.coresta.org/abstracts/role-nitrogenoxides-tobacco-specific-nitrosamine-formation-burley-tobacco2254.html.

[16] H. Shi, R. Wang, L. P. Bush et al., "Changes in TSNA contents during tobacco storage and the effect of temperature and nitrate level on TSNA formation," Journal of Agricultural and Food Chemistry, vol. 61, no. 47, pp. 11588-11594, 2013.

[17] W. Morgan, J. Reece, C. Risner et al., "A collaborative study for the determination of tobacco specific nitrosamines in tobacco," Beiträge zur Tabakforschung International, vol. 21, no. 3, pp. 192203, 2014.

[18] J. Zhou, R. Bai, and Y. Zhu, "Determination of four tobaccospecific nitrosamines in mainstream cigarette smoke by gas chromatography/ion trap mass spectrometry," Rapid Communications in Mass Spectrometry, vol. 21, no. 24, pp. 4086-4092, 2007.

[19] J. D. Crutchfield and J. H. Grove, "A new cadmium reduction device for the microplate determination of nitrate in water, soil, plant tissue, and physiological fluids," Journal of AOAC International, vol. 94, no. 6, pp. 1896-1905, 2011.

[20] A. Jack and L. Bush, The 'LC' Protocol-Appendix 3: Laboratory Procedures, University of Kentucky, Lexington, Ky, USA, 2007, http://www.uky.edu/Ag/Tobacco/Pdf/LC-Protocol.Pdf.

[21] L. P. Bush, M. W. Cui, and H. Z. Shi, "Formation of tobaccospecific nitrosamines in air-cured tobacco," in Proceedings of the 55th Tobacco Science Research Conference, Greensboro, NC, USA, September 2001.

[22] H. Shi, N. E. Kalengamaliro, M. R. Krauss, W. P. Hempfling, and F. Gadani, "Stimulation of nicotine demethylation by $\mathrm{NaHCO}_{3}$ treatment using greenhouse-grown burley tobacco," Journal of Agricultural and Food Chemistry, vol. 51, no. 26, pp. 7679-7683, 2003.

[23] H. Shi, R. Wang, L. P. Bush, H. Yang, and F. F. Fannin, "The relationships between TSNAs and their precursors in burley tobacco from different regions and varieties," Journal of Food, Agriculture and Environment, vol. 10, no. 3-4, pp. 1048-1052, 2012.

[24] R. S. Lewis, R. G. Parker, D. A. Danehower et al., "Impact of alleles at the Yellow Burley (Yb) loci and nitrogen fertilization rate on nitrogen utilization efficiency and tobacco-specific nitrosamine (TSNA) formation in air-cured tobacco," Journal of Agricultural and Food Chemistry, vol. 60, no. 25, pp. 6454-6461, 2012. 
[25] W. J. Zhang, S. Rabiei, A. Bagreev, M. S. Zhuang, and F. Rasouli, "Study of NO adsorption on activated carbons," Applied Catalysis B: Environmental, vol. 83, no. 1-2, pp. 63-71, 2008.

[26] D. M. Peele, M. G. Riddick, and M. E. Edwards, "Formation of tobacco specific nitrosamines in flue-cured tobacco," Recent Advances in Tobacco Science, vol. 27, pp. 3-12, 2001.

[27] G. H. Ellington and M. D. Boyette, "Investigation into the correlation among nitrogen oxides and tobacco-specific nitrosamine in flue-cured tobacco," Tobacco Science, vol. 50, pp. 11-18, 2013.

[28] S. Tatsuoka, "Process for producing regenerated tobacco material," EP Patent:1782702 A1, 2005, http://www.freepatentsonline .com/EP1782702.html.

[29] X. D. Sun, W. G. Lin, L.-J. Wang et al., "Liquid adsorption of tobacco specific N-nitrosamines by zeolite and activated carbon," Microporous and Mesoporous Materials, vol. 200, pp. 260 268, 2014.

[30] W. G. Lin, B. C. Huang, B. Zhou et al., "Trapping tobacco specific N-nitrosamines in Chinese-Virginia type tobacco extracting solution by porous material," Journal of Porous Materials, vol. 21, no. 3, pp. 311-320, 2014. 

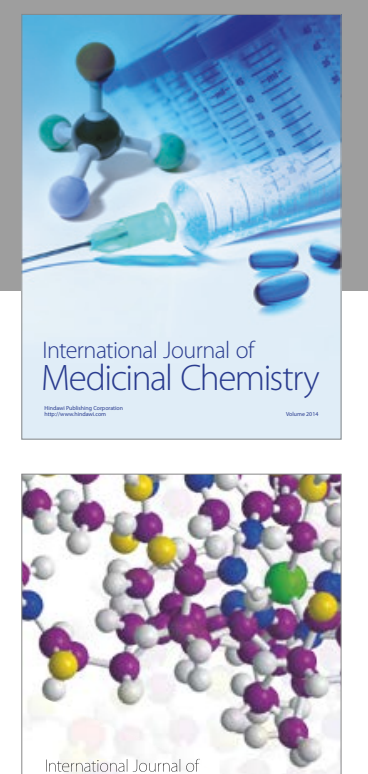

Carbohydrate Chemistry

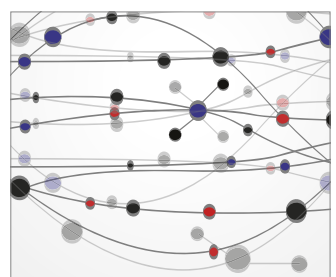

The Scientific World Journal
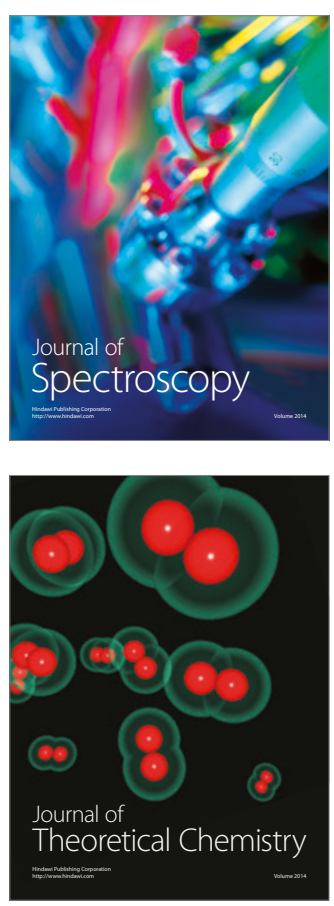
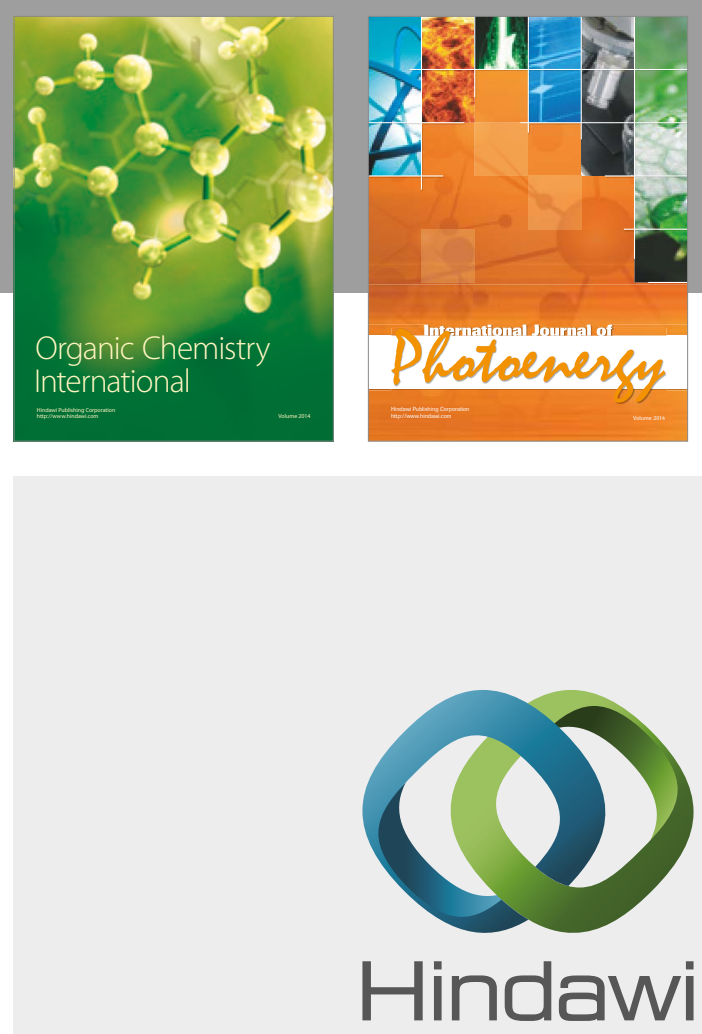

Submit your manuscripts at

https://www.hindawi.com

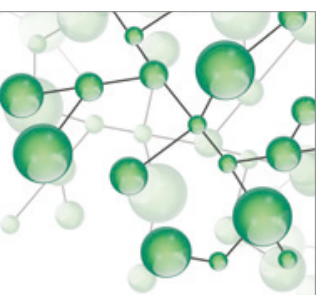

International Journal of

Inorganic Chemistry

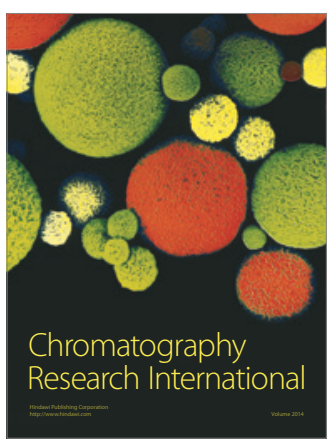

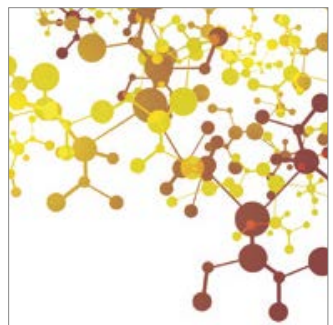

Applied Chemistry
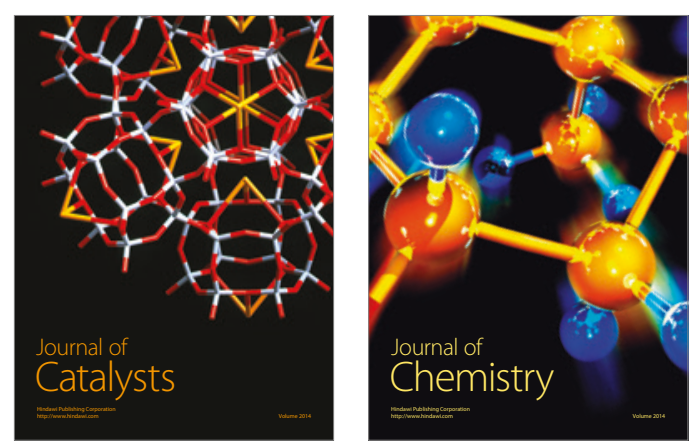
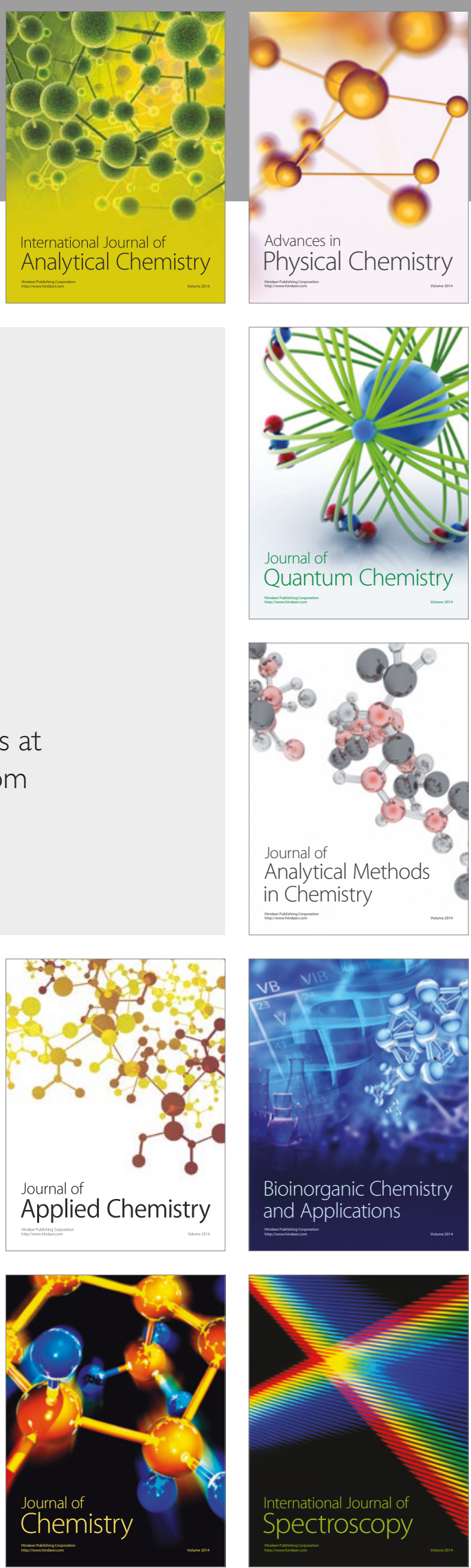